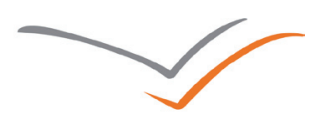

STUDIA HISTORIAE OECONOMICAE

UAM Vol. $31 \quad$ Poznań 2013

\title{
VERSITA
}

Bartłomiej Garczyk (Adam Mickiewicz University, Poznań)

\section{ETHNIC STRUCTURE OF \\ ST PETERSBURG - PETROGRAD - LENINGRAD IN THE PERIOD OF 1703-1991}

This article presents a multinational and multireligious character of St. Petersburg since the founding of the city to the collapse of the Soviet Union. An ethnic and cultural mosaic was also an important feature in other centers of Russia, including Moscow and Odessa, as well as forming part of the national capital of the Russian Empire in Warsaw, Riga and Tallinn. St. Petersburg is a city but of a symbolic and unique character. It is the subject of literary impressions and creative inspiration for generations of artists. In addition, St. Petersburg - Petrograd - Leningrad was the capital of a multinational and multireligious Russian Empire, Soviet Russia, and since 1918, it was the second most important city of the Soviet Union. The author's intention is also to present the history of St. Petersburg - Petrograd - Leningrad, as seen through the prism of the history of national minorities living in it.

Keywords: St Petersburg, Petrograd, Leningrad, ethnic structure, peoples/nations, national minority, the USSR, the Soviet ethnic policy, censuses of St Petersburg's population.

doi:10.2478/sho-2013-0006

St Petersburg is a symbolic and unique city which was the object of many impressionistic literary works and which inspired numerous generations of artists. In line with - what may be called - "the traditional" history of St Petersburg, full of glamour, elegance and beauty of the architecture, a less known history exists. In addition to the St Petersburg of Peter I, the St Petersburg of Rastrelli, Pushkin, Mickiewicz, Dostoyevski and Gogol, there is another history of German, Polish, Finnish, Swedish, Italian or Jewish people who settled upon the Neva River. Numerous national minorities of St Petersburg left a distinctive impression on the city life. Different nations, denominations, traditions and customs were interwoven and interacted with each other. The national diasporas which lived in the city intensively identified themselves with it and participated in the 
development of its diversified culture. Consequently, "the ethnic history" constitutes a crucial element in acquiring the full knowledge about the phenomenon of the northern Russian capital city.

Since its very beginning, St Petersburg has been a multinational city. Its multi-ethnic and multi-denominational character was a product of three factors.

Firstly: St Petersburg was a political, administrative, commercial, industrial and cultural center of the vast Russian empire (and also one of the main political centers of Europe). In the first decades of its existence, St Petersburg attracted mainly Russian subjects and foreigners (immigrants) - mainly of English, German, Swedish, French and Italian nationality. The subjects of the Russian empire who were not Russians did not come to St Petersburg until the beginning of 19th century. This resulted from the fact that in the early 18th century territories of Poland, Lithuania and Caucasus were still not incorporated within Russian borders. The inflow of population into St Petersburg resulted initially from compulsory migration. Active construction of the city required a vast workforce. That is why each year thousands of Russian peasants were sent to the city under tsar's ukases. With the passing of time foreign specialists and craftsmen started to come as well. What is more, foreign engineers as well as scientists, doctors, architects and artists were invited to Russia. Also European merchants arrived in the city in great numbers. Foreigners played a significant role in the life of Russia and St Petersburg. They substantially contributed to the development of Russian civilization, especially its social, economic and cultural life. The comprehensive input of numerous outstanding foreign architects and sculptors should be emphasised. They include Frenchmen such as Jean Baptiste Alexandre Leblond (1679-1719), Jean Vallin de la Mothe (1729-1800), and Thomas de Thomon (1760-1813); Italians, Domenico Trezzini (1670-1734) Bartolomeo Rastrelli (1700-1771), Carlo Rossi (1775-1849); Germans, Juri Felten (17301801), Konstanty Thon (1794-1881), Peter von Clodt (1805-1867) and many more. Foreigners played an important role in creating and developing Russian science and education, and they occupied a key place in the history of Russian central and local administration, army, diplomacy and acted as spiritus movens for the development of Russian industry.

Secondly, as the capital city, St Petersburg was a "reflection" of the multinational character of the Russian Empire. The diversified ethnic structure of Russia stemmed from centuries-old political and military expansion of the Russian state and the accompanying colonisation processes. The incorporation of the vast areas of the Polish-Lithuanian Commonwealth 
(Rzeczpospolita Obojga Narodów), the Baltic territories and Finland within the boundaries of the Empire was of special significance to the city's ethnic structure ${ }^{1}$.

Thirdly, St Petersburg was located on the outskirts of the lands which ethnically belonged to Great Russia. The city was built in the territory of Ingria (in German, Ingermanlandia; in Russian, Izhorian Land), incorporating the area between Estonia and Karelia - located alongside the south, east and north coast of the Finnish Lagoon. Throughout the centuries this territory became the scene of Russian and Swedish military rivalry. The army of the Livonian Brothers of the Sword and the Polish army also periodically participated in those military actions. Long wars and territorial and political changes heavily influenced the ethnic shape of the described territories. Northwestern Russia, including Ingria from which the St Petersburg province was to be separated in the future, was initially occupied by Finno-Ugric tribes: Votes, Izhorians, Vepsians and Karelians. The first Russian tribes - Ilmen Slavs and Novgorod Slavs - settled there in the seventh and eighth centuries. From the eleventh to the fourteenth century vast areas of northwestern Russia were controlled by Veliky Novgorod. The colonization that was initiated by this group of people established economic and administrative supremacy over the indigenous population, which in turn led to cultural and denominational assimilation. Later Swedish occupation changed the ethnic structure of Ingermanlandia. The population, already primarily Orthodox in their faith, left their settlements and were replaced by Swedish and German feudal lords and a Lutheran population, mainly consisting of Finnish and Swedish peasants. The peace agreement in Nystad concluding the Great Northern War (1700-1721) officially sanctioned the return of Ingria to Russia, and a secondary russification started in the incorporated territories. As a result of the above, the lands surrounding St Petersburg acquired a diversified ethnic structure upon setting up the capital city:

a. the first ethnic group consisted of an indigenous Finn-Ugric population: Izhorians, Votes, Vepsians and Karelians;

1 The process of formation of a multinational Russian state is described in: А. Каппелер, Россия - многонациональная империя. Возникновение, история, расnаd, Moskow 2000; compare with W. Zajączkowski, Rosja i narody. Ósmy kontynent, szkic dziejów Eurazji, Warszawa 2009. Multi-ethnicity is not only attributable to St Petersburg. A multinational mosaic is typical of capital cities, ports, industrial and cultural centers. So multinationality is a domain of many European cities. Moscow and Odessa were also ethnically diversified as well as the capital cities incorporated in the Russian Empire such as Warsaw, Riga and Tallin. 
b. the second group consisted of Russians, predecessors of the population of Novgorod Republic;

c. the third group consisted of Russian serfs, displaced people from other Russian provinces;

d. the fourth group consisted of Lutheran Finns who settled in Ingria during the Swedish occupation in 17th century, the so-called Ingermanland Finns

e. the fifth group consisted of the population migrating to the Russian capital city - both the foreigners (subjects of foreign states) and non-Russians (subjects of the Russian empire) ${ }^{2}$.

In order to get information about the number and ethnic composition of St Petersburg residents, it is necessary to browse through the official statistics. Censuses were the main, although not the sole, source of information concerning the dynamics of demographic processes in the tsarist Russia (including St Petersburg). Some information may also be found in church statistics and police registers and reports. The census of 28 January 1897 was the first and the only universally national census in the Russian empire. Municipal censuses were also carried out, for example, in Moscow, Warsaw and Odessa. In St Petersburg municipal censuses were carried out regularly every 10 years. The first one was held in 1869, and the subsequent ones in 1881, 1890, 1900 and 1910. A researcher trying to figure out the ethnic structure of the city may encounter incomplete statistics of tsarist Russia in the nineteenth century. In those censuses the nationality was established on the basis of the language (роднои язык), replacing the question about nationality. In this way the ethnic composition of the population in the censuses before the revolution was limited to presentation of the language structure and not the sense of national identity. What is more, the Russian statistics treated the notion of a native language (mother tongue) differently. In the guidelines to the municipal census of 1869 the native language was understood as a mother tongue (материнский язык), and in the guidelines to the census of 1881 the native language was understood as the language that was spoken (разговорныи язык). This free interpretation affected the results of the censuses ${ }^{3}$. Improper use of the term "the Russians" with respect to the contemporary point of view (Рyсckue)

2 Н. В. Юхнева, Многонациональная столица империи, [in:] И.И. Шангина (Еd.), Многонациональный Петербург. История. Религии. Народы, St Petersburg 2002, pp. 15-6.

${ }^{3}$ For more information, Н. В. Юхнева, К методике использования петербургских переписей населения кониуа ХІХ - начала XX в. в этнографических исследованиях, [in:] 
was another defect. The ethnonym "the Russians" was understood to include two meanings: as designating three East-Slavic nations of Russians, Ukrainians and Belorussians as well as a synonym of the Russian nation (of the Great Russia) ${ }^{4}$. As a consequence, the data contained in the censuses frequently did not reflect the actual ethnic situation, overstating or understating the number of given nationalities.

Under the circumstances of a dominating Russian culture, the life in a Russian city required fluency in speaking the Russian language. Mixednationality marriages, different senses of national identity and the size of particular ethnic minorities subjected the population of St Petersburg to the processes of mutual acculturation to a greater or lesser extent and supported linguistic assimilation. However, as the Russian researcher Natalia Juchniewa points out, the degree of assimilation was not equal: "ranging from insignificant cultural borrowings and bilingualism - through permanent switching to the Russian language and conversion into Orthodox faith - to full assimilation and conversion into Russians" ${ }^{\prime 5}$. Permanent switching to the Russian language led, in the case of censuses based on the language criterion, to registration of the representatives of many nonRussian nationalities, with Ukrainians and Belorussians in particular, under "the Russians" heading. Tsarist censuses also overstated the size of the German population. Austrian, Swiss and partially Estonian people were registered under "the Germans" heading. Taking the above into consideration, a critical analysis of the tsarist censuses shall also, in addition to the language criterion, take into account extra criteria differentiating the ethnicity. Denomination, geographical origin and social status are some of the most important criteria:

Religion may be helpful in determination of ethnicity (...). For instance, (...) Crimean Muslims are mostly Tatars. Lutherans in St Petersburg can be German as well as Swedish, Finnish, Estonian and Latvian (...). Lutherans in Saratov Oblast must be German. If two nations in the same territory share the same denomination, their social status, profession etc. can help in determining their ethnicity. For example, in St Petersburg the Lutheran gentry are bound to Germans, and not Finns or Estonians (...). Peasants from Minsk or Mogilev Province are bound to be Belorussians.

Н. В. Юхнева (еd), Этнография Петербурга - Ленинграда. Тридияать лет изучения 1974 2004, St Petersburg 2004, p. 60ff.

${ }^{4}$ Н. В. Юхнева, К методике использования петербургских переписей, p. 65; compare also: Н. В. Юхнева, Многонациональная столица империи, р. 22.

${ }^{5}$ Н. В. Юхнева, Петербург на рубеже ХІХ - ХХ веков. Этнические проблемы мегаполиса, [in:] Н. В. Юхнева, Статьи разных лет, St Petersburg 2005, p. 80. 
Gaining information about the actual size of particular nationalities in St Petersburg is possible thanks to performing a scientific reconstruction. An example concerning Ukrainians and Belorussians proves how crucial it is to take into account non-language criteria in ethnic analysis. In the censuses performed in 1881, 1890, 1900 and 1910 the use of the Ukrainian language was declared by 300, 700, 1,500 and 2,900 people respectively. The reconstruction was performed to verify the number of Ukrainians and Belorussians, and the results are presented in the table below.

Table 1. Reconstruction of the number of Ukrainians and Belorussians

\begin{tabular}{lcccc}
\hline & 1881 & 1890 & 1900 & 1910 \\
\hline $\begin{array}{l}\text { Number of Ukrainians according } \\
\text { to the language criterion declared } \\
\text { in the census }\end{array}$ & $\begin{array}{c}0.3 \\
\text { thousand }\end{array}$ & $\begin{array}{c}0.7 \\
\text { thousand }\end{array}$ & $\begin{array}{c}1.5 \\
\text { thousand }\end{array}$ & $\begin{array}{c}2.9 \\
\text { thousand }\end{array}$ \\
\hline $\begin{array}{l}\text { Reconstruction of the number of } \\
\text { Ukrainians }\end{array}$ & $\begin{array}{c}1.4 \\
\text { thousand }\end{array}$ & $\begin{array}{c}5.0 \\
\text { thousand }\end{array}$ & $\begin{array}{c}10.6 \\
\text { thousand }\end{array}$ & $\begin{array}{c}17.0 \\
\text { thousand }\end{array}$ \\
\hline $\begin{array}{l}\text { Number of Belorussians according } \\
\text { to the language criterion declared } \\
\text { in the census }\end{array}$ & - & $\begin{array}{c}0.3 \\
\text { thousand }\end{array}$ & $\begin{array}{c}0.8 \\
\text { thousand }\end{array}$ & $\begin{array}{c}2.2 \\
\text { thousand }\end{array}$ \\
\hline $\begin{array}{l}\text { Reconstruction of the number of } \\
\text { Belorussians }\end{array}$ & $\begin{array}{c}7.0 \\
\text { thousand }\end{array}$ & $\begin{array}{c}13.0 \\
\text { thousand }\end{array}$ & $\begin{array}{c}42.0 \\
\text { thousand }\end{array}$ & $\begin{array}{c}70.0 \\
\text { thousand }\end{array}$ \\
\hline
\end{tabular}

Source: Н. В. Юхнева, “К методике использования петербургских переписей населения конца XIX - начала XX в. в этнографических исследованиях", in Н. В. Юхнева (ed), Этнография Петербурга - Ленинграда. Тридиать лет изучения 1974 - 2004, St Petersburg 2004, p. 67.

The first information about demographic structure of St Petersburg originates from the reports of the superintendents of St Petersburg police. However, this data is very slight and imprecise. In accordance with the police specification in 1818, St Petersburg had a population of 386,000 residents, including about 35,000 non-Russians, or $9 \%$ of the total population $^{6}$. In accordance with the first official municipal census of 1869, the St Petersburg population amounted to 667,200, including 555,000 (83.2\%) Russians ${ }^{7}$. The most numerous diasporas included Germans 45,600 (6.8\%),

${ }^{6}$ А. И. Копанев, Население Петербурга в первой половине ХІХ века, Leningrad 1958, pp. 17, 20.

${ }^{7}$ For the statistical data of the tsarist censuses up to 1917 see: Н. В. Юхнева, Этнический состав и этносоииальная структура населения Петербурга. Вторая половина ХІХ - начало XX века, Leningrad 1984. 


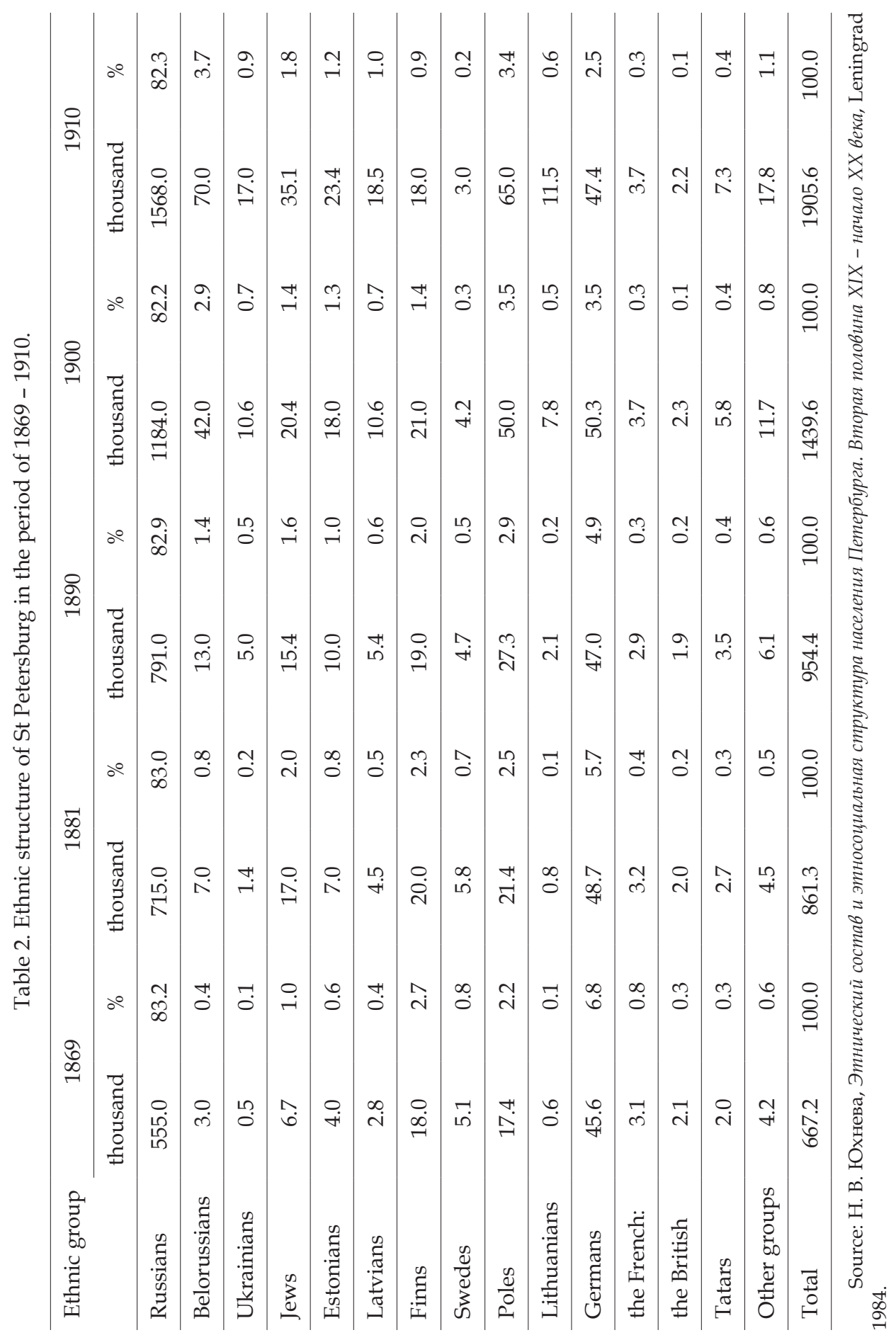


Finns 18,000 (2.7\%), Poles 17,400 (2.2\%) and Jews 6,700 (1\%). The nonRussian population constituted $17 \%$ of the total population. In the next decades the number of Russians stabilized, oscillating between $82 \%$ and $83 \%$. Changes affected non-Russian ethnic groups. The number of Poles, Belorussians, Ukrainians, Estonians and Latvians was regularly growing; whereas the number of Germans and Finns was decreasing. Most of the foreigners residing in St Petersburg were French, and their number in the censuses oscillated between 2,199 and 2,683. The number of British in the period of 1869-1910 increased from 1,709 to 2,260. In the analogous period the number of the Swiss increased from 551 to 1,187. The Italian diaspora increased from 424 people in 1869 to 611 in 1910 . The mosaic of the national minorities was also becoming more elaborate.

Tsarist censuses of the population of St Petersburg give also interesting information about the so-called ethnic topography of the city, namely distribution of particular ethnic groups within the city boundaries and their social and professional structure. This valuable material has not been fully analysed and used in the literature yet. The location of the groups of the non-Russian population was of a dual character. In the first decades of its existence St Petersburg did not have any systematic plan and consisted of randomly scattered housing estates and settlements. Those estates were populated with the people of a given social status or practiced profession, which was later reflected in the toponymy of the city, e.g. ямская слобода, литейная слобода. Also the ethnic groups resided in particular districts of the city, forming dense centres and clusters. The Russian enclave (русская слобода) located east of the Peter and Paul Fortress was one of them. Another one - the Tatar enclave (mamapckar слобода), was formed at the beginning of 18th century north of the Peter and Paul Fortress. In different periods on the left bank of the Neva River subsequent enclaves were established: the German, French and British, with the latter consisting almost exclusively of foreign merchants, situated near the Admiralty Building, where the contemporary British Quay can now be found. This topographic mode existed more or less until the beginning of 19th century. Later on, in line with the development of the capital city and the administrative changes, the ethnic topography of the city changed. The mode of distribution of population then changed from a dense one into a dispersed (or scattered) one, and the ethnic enclaves became indistinguishable.

The professional structure of the population of St Petersburg, depicted in the table below, is also worth noting. 
Table 3. Ethnic composition of given professions in 1869

\begin{tabular}{|c|c|c|c|}
\hline Profession & Total number & Nationality & $\%$ \\
\hline \multirow{4}{*}{$\begin{array}{l}\text { Cart and carriage } \\
\text { drivers }\end{array}$} & \multirow[t]{4}{*}{$15991(100 \%)$} & Russians & 92.4 \\
\hline & & Finns & 4.6 \\
\hline & & Estonians & 1.7 \\
\hline & & Others & 1.3 \\
\hline \multirow[t]{9}{*}{ Domestic servants } & \multirow[t]{9}{*}{18433} & Russians & 94.5 \\
\hline & & Poles & 1.6 \\
\hline & & Germans & 0.8 \\
\hline & & Finns & 0.6 \\
\hline & & Latvians & 0.5 \\
\hline & & Tatars & 0.5 \\
\hline & & Estonians & 0.3 \\
\hline & & Jews & 0.3 \\
\hline & & Others & 0.9 \\
\hline \multirow{4}{*}{$\begin{array}{l}\text { Hotel and restraurant } \\
\text { staff }\end{array}$} & \multirow[t]{4}{*}{6277} & Russians & 95.5 \\
\hline & & Tatars & 1.9 \\
\hline & & Germans & 1.6 \\
\hline & & Others & 1.0 \\
\hline \multirow{3}{*}{$\begin{array}{l}\text { Hotel and restaurant } \\
\text { owners }\end{array}$} & \multirow[t]{3}{*}{370} & Russians & 91.1 \\
\hline & & Germans & 5.7 \\
\hline & & Others & 3.2 \\
\hline \multirow[t]{5}{*}{ Blacksmiths } & \multirow[t]{5}{*}{2123} & Russians & 90.0 \\
\hline & & Germans & 3.5 \\
\hline & & Finns & 2.0 \\
\hline & & Swedes & 0.3 \\
\hline & & Others & 4.2 \\
\hline \multirow[t]{6}{*}{ Clockmakers } & \multirow[t]{6}{*}{518} & Russians & 34.0 \\
\hline & & Germans & 37.0 \\
\hline & & Swedes & 11.0 \\
\hline & & Finns & 9.3 \\
\hline & & Jews & 3.0 \\
\hline & & Others & 5.7 \\
\hline \multirow[t]{5}{*}{ Jewellers } & \multirow[t]{5}{*}{2438} & Russians & 52.0 \\
\hline & & Finns & 23.0 \\
\hline & & Germans & 13.4 \\
\hline & & Swedes & 6.0 \\
\hline & & Others & 5.6 \\
\hline \multirow[t]{5}{*}{ Bakers } & \multirow[t]{5}{*}{2818} & Russians & 68.0 \\
\hline & & Germans & 25.0 \\
\hline & & Finns & 4.5 \\
\hline & & Swedes & 0.7 \\
\hline & & Others & 1.8 \\
\hline
\end{tabular}


tab. 3 continue

\begin{tabular}{lclr}
\hline \multicolumn{1}{c}{ Profession } & Total number & \multicolumn{1}{c}{ Nationality } & $\%$ \\
\hline Doctors & \multirow{2}{*}{916} & Russians & 43.7 \\
& & Germans & 34.3 \\
& & Poles & 6.7 \\
& & Jews & 2.2 \\
& & Others & 13.1 \\
\hline \multirow{2}{*}{ Academic teachers } & \multirow{2}{*}{172} & Russians & 76.2 \\
& & Germans & 9.3 \\
& & Poles & 4.1 \\
& & Others & 10.4 \\
\hline
\end{tabular}

Source: Н.В. Юхнева, Этнический состав..., pр. 49-75.

In terms of the professional structure of St Petersburg in 1869, as well as in other fields of economy, the Russians constituted the prevailing majority. However, this was not a fixed principle. There were some professions in which the dominating position of the Russians was taken over by other ethnic groups. Such professions include clockmakers and jewellers, where the percentage of Russians amounted only to 34\% and 52\% accordingly. Other professions such as blacksmith, locksmith, tailor and carpenter were typically performed by Germans. Germans also dominated the art of clock making, baking and factory ownership. Similarly to Germans, Finns and Swedes also constituted a high percentage of locksmiths, blacksmiths, jewellers, clockmakers, shoemakers, tailors and carpenters. Most cart and carriage drivers were Finns. Most waiters and restaurant, inn, tavern and hotel staff were Tatars. Among the local intelligentsia in the engineering group, the Russians accounted for more than $40 \%$. Other ethnic groups consisted mainly of Germans, the British, the French and Poles. Out of 916 of St Petersburg doctors, 44\% were Russian, 34\% were German and almost $7 \%$ were Polish. Most of academic lecturers and teachers were German, Polish and French. 29\% of private tutors were German, and $12.6 \%$ were French. $81.4 \%$ Russian, $6.5 \%$ Germans, $4.5 \%$ Poles and $7.6 \%$ of other nationals worked in the state and public administration. It must be emphasised, however, that Russians who held the highest positions in the administrative ladder; the lower position, the greater the number of nonRussians.

Up to the 1917 revolution the national minorities populating St Petersburg were vastly different in terms of size and religion. The degree of their economic development and social and professional structure 
was dissimilar. Their national identity developed heterogeneously; the origins of their influx into the city were different, as was their susceptibility to the assimilation process. It has to be emphasised that nations with a rich culture, well-developed literary language and traditions were treated differently by the tsar than nations with a low consciousness of the nationality. On the one hand, the nations' having a tradition of their own statehood often showed a tendency for confrontation, which was met with opposition of the authorities and led to the increased use of repressive measures. On the other hand, the nations' lacking such traditions were not interested in regaining lost independence, but rather showing conformism. Depending on the changes in the ethnic policy of the tsar, particular national minorities residing in St Petersburg gained greater or lesser freedom to acting and implement their national aspirations. Their own cultural and national needs were expressed in different forms. The most popular forms were through the establishment of cultural, educational, charitable, social, sport and other organizations. The press was available in the national language, national schools, secondary schools, libraries, reading rooms, clubs, churches and places of worship which were set up and built ${ }^{8}$.

Another census covering the whole of Russia was planned for 1916, but the outbreak of World War I prevented it. War, revolution and civil strife greatly affected the ethnic structure of Petrograd - Leningrad. It is extremely difficult to analyse precisely the ethnic processes of that period, due to very scarce source materials. In the period of 1917 - 1923 a few censuses were carried out. However, as many authors emphasise, their academic value is limited and the censuses may raise doubts ${ }^{9}$. For example, the 1920 census was carried out only in a part of the territory and at a time when vast areas of Russia were affected by civil war. For clear reasons this census could not have been fully representative.

In the period of 1916 - 1920 the demographic structure of Petrograd underwent significant changes. The Great War and two revolutions - as well as the facts related therewith such as army mobilisation, the worsening of the living and economic standards, the food deficit and mass unem-

${ }^{8}$ More details about this subject can be found in the work of B. Garczyk, Radziecka polityka narodowościowa w latach 1917-1941 na przykładzie Piotrogrodu - Leningradu, Poznań 2011. The multinational character of St Petersburg will be described in the book titled St Petersburg - nierosyjska historia miasta 1703-1917, which was submitted for publication.

9 Sее Ю.А. Поляков, Население России В ХХ Веке. Исторические очерки, т. 1, 1900 - 1939 гг., Moscow 2000, pp. 91-3; Ю. А.Поляков, И.Н. Киселев, Численность и национальный состав населения России В 1917 году, Вопросы истории № 6/1980, pp. 39-40. 
ployment led to intensive depopulation of the city. Further demographic changes resulted from the end of the civil war, following the victory of the Bolshevik revolution the great shifting of borders and the creation of new independent national states neighbouring the USSR. In 1920 the population of Petrograd amounted only to 722,000. If compared with 1917 the population of Petrograd amounted to 2.3 million. ${ }^{10}$ Simultaneously numerous refugees arrived from the areas occupied by the German army (the Baltic states, Belorussia and Ukraine). Among these included Poles, Belorussians, Lithuanians, Jews and Latvians. And at the beginning of World War I the subjects of the Austro-Hungarian Empire and of Germany left St Petersburg. This resulted in the all-time highest percentage of nonRussian population of Petrograd, reaching 25\%. In the subsequent years the number of Poles, Latvians, Lithuanians and Estonians - the nationalities whose native national centres happened to be located outside the USSR after the revolution - decreased in Petrograd. The following diasporas practically disappeared from the ethnic plan of the city: the British, French, Swedish and Dutch.

In 1926 the first post-revolutionary national census took place. This census was conducted in a very precise and detailed way, forming the elementary source base of the demographic processes of the early existence of the USSR ${ }^{11}$. Here it is worth mentioning that the Russian statistics of the 1920s was in its heyday. It was supervised by such outstanding Soviet specialist demographers as Wasilij Michajłowskij and Olimp Kwitkin. The 1926 census was conducted under circumstances of full disclosure, without any political pressure, pursuant to and with the use of the latest knowhow and research methods ${ }^{12}$. What is important, apart from the question about the language, is that the census included a question about nationality ${ }^{13}$. According to the census, the population of Leningrad amounted

10 The statistical data quoted by me for the period 1917-1939 originate from Т. М. Смирнова, Национальность - питерские. Национальные меньшинства Петербурга и Ленинградской области в XX веке, St Petersburg 2002; See also Всесоюзная перепись населения 1939 года. Основные итоги. Россия, St Petersburg 1999 and Всесоюзная перепись населения 1937 г. Краткие итоги, Moscow 1991.

11 A. Maryański, Przemiany ludnościowe w ZSRR, Warszawa-Kraków 1995, pp. 7-8.

12 A lot of interesting information concerning the preparation and performance of the Soviet censuses may be found in the article: В.Б. Жиромская, Всесоюзные переписи населения 1926, 1937, 1939 годов. История подготовки и проведения, История СССР, № 3/1990, p. 84 .

13 Although as early as in 1872 during the International Statistical Congress in St Petersburg a thesis was advanced that it is self-determination by the respondent, and 
to $1,609,000$ including $1,386,900$ Russians (86.15\%). Jews were the biggest non-Russian ethnic group at 84,500 (5.31\%). Dynamic growth of the population of Jewish origin was prompted by the change in tsarist, anti-Jewish legislation along with a wave of pogroms against Jews in Ukraine and Belorussia in the period between 1918 - 1922. Poles formed the second biggest non-Russian group, although their number decreased in comparison with 1910 from 65,000 to 34,000 (2.1\%). There was a decrease also in the number of other national groups - Germans from 47,000 in 1910 to $16,900(1.0 \%)$, Estonians from 23,400 to 15,800 (1\%), Belorussians from 70,000 to $14,500(0.9 \%)$. In total the non-Russian national minorities accounted for almost $14 \%$ of the total population. The census included also very small ethnic groups constituting not more than $1 \%$. They included inter alia the Greek, Chinese, Gypsies, Ossetians, and Georgians.

After the Bolshevik revolution of 1917, the Bolsheviks began to implement the principles of the Lenin ethnic policy under which the so-called korenization (indigenization) was proclaimed. Its purpose was to involve the national minorities in the social and political activities and at the same time to naturalize the state, party and social apparatus as well as to promote the native language of the minorities in the state institutions. The construction of such cultural facilities took place on an unprecedented scale in Russia and Leningrad including the establishment of organizations of national minorities, national clubs, cultural centres, libraries, theatres, and the press. This construction, however, had precisely defined ideological frames. In the 1930s there was a turnabout in the Soviet ethnic policy which had tragic consequences. In the Stalinist era a brutal destruction of the culture of national minorities in Leningrad took place. National clubs, publishing houses and schools were closed down, and churches and necropolises were demolished. As an example of the barbaric and anti-religious policy of the authorities, we may cite the horrifying way the Wyborski Catholic Cemetery and the St Peter Protestant Church on Nevsky Avenue were treated. Ubiquitous terror, repressions - including the sinister years of 1937 and 1938 - as well as deportations led almost to the extinction of national minorities residing upon the Neva River. Being afraid of persecutions, people stopped speaking their mother tongues even at home. Many

not the language, which forms the basic criterion for the ethnicity, this thesis was not practically reflected until the Soviet censuses. 
survived but the years of Stalinist repressions left a distinctive impression on their psyche ${ }^{14}$.

Another Soviet census was conducted in 1937 in the period of Stalinist repressions and had a propagandist character. In accordance with the assumptions of the Soviet authorities and the rhetoric of this time, the census was to show the supremacy of communism over capitalism. The planned increase in the USSR population, from 147 million in 1926, to180 million in 1937, and the high degree of godlessness of the Soviet society was to confirm the achievements of the Socialist architecture. Given the mass repressions of the 1930s, great a famine, collectivization and the extermination of millions of people, the results of the census were unable to confirm the official Stalinist forecasts. Both the "triumphant march of atheism" and the expected baby boom turned out to be only a pretence. In 1937 the population of the USSR amounted only to 162 million, and the number of atheists amounted to $42.9 \%$ (42.3\%, members of Orthodox Church, $0.5 \%$ Protestants, $0.3 \%$ Jews, and $8.4 \%$ Muslims $)^{15}$. The census itself and the organizers and researchers in charge of conducting it all suffered tragic endings.. Being afraid of an international scandal and revealing the murderous character of the regime, the authorities decided to make the census documents fully confidential, and the people in charge of conducting the census, including Iwan Krawal and Olimp Kwitkin, were repressed and murdered ${ }^{16}$. In accordance with the census, the population of Leningrad amounted to 2,826,100 residents, including 2,435,500 (86.2\%) Russians. The Jewish diaspora of 185,200 (6.55\%) and the Ukrainian diaspora of 37,800 $(1.33 \%)$ constituted the biggest non-Russian groups. The Polish minority amounted to $31,200(1.1 \%)$ constituting over $1 \%$.

In 1939 the third (officially the second) universal Soviet census took place. Its main purpose was to correct the reputedly "defective" census of 1937. Currently many authors challenge its academic value as it was conducted in a nervous atmosphere, at the bidding of the authorities desiring to attain a specific propaganda result. This census may have been falsified, and its data may have been overstated. In accordance with official information the Leningrad population reached 3,191,300, including 2,776,000

14 More in B. Garczyk, Radziecka polityka narodowościowa..., pp. 91-241.

15 The question about religion appeared only in two censuses - in 1897 and 1937. Seе O.Е. Казьмина, Вопрос о религиозной принадлежности в переписях населения России и СССР, Этнографическое обозрение, № 5/1997.

16 В.Б. Жиромская, Всесоюзные переписи населения 1926, 1937, 1939 годов. История подготовки и проведения, История СССР, № 3/1990, р. 85. 
(87\%) Russians. The number of Jews, Ukrainians, Belorussians and Tatars also rose. Other minorities decreased their number.

Table 4. Ethnic structure of Petrograd - Leningrad in the period of 1926 - 1939.

\begin{tabular}{lrrrrrr}
\hline \multirow{2}{*}{ Ethnic group } & \multicolumn{2}{c}{1926} & \multicolumn{2}{c}{1937} & \multicolumn{2}{c}{1939} \\
\cline { 2 - 7 } & thousand & $\%$ & thousand & $\%$ & thousand & $\%$ \\
\hline Russians & 1386.9 & 86.15 & 2435.5 & 86.2 & 2776.0 & 87.0 \\
\hline Belorussians & 14.6 & 0.9 & 26.3 & 0.93 & 32.4 & 1.0 \\
\hline Ukrainians & 10.8 & 0.7 & 37.8 & 1.33 & 54.7 & 1.7 \\
\hline Jews & 84.5 & 5.3 & 185.2 & 6.55 & 201.5 & 6.3 \\
\hline Estonians & 15.8 & 1.0 & 16.9 & 0.6 & 15.2 & 0.5 \\
\hline Latvians & 12.9 & 0.8 & 12.3 & 0.44 & & - \\
\hline Finns & 6.7 & 0.4 & 8.7 & 0.3 & 7.9 & 0.2 \\
\hline Poles & 34.0 & 2.1 & 31.2 & 1.1 & 20.6 & 0.6 \\
\hline Lithuanians & 5.9 & 0.4 & - & - & - & - \\
\hline Germans & 16.9 & 1.0 & 16.8 & 0.6 & 10.1 & 0.3 \\
\hline Tatars & 7.3 & 0.5 & 26.6 & 0.94 & 31.5 & 1.0 \\
\hline Other groups & 13.5 & 0.8 & 28.8 & 1.01 & 62.1 & 1.9 \\
\hline Total & 1609.8 & 100.0 & 2826.1 & 100.0 & 3191.3 & 100.0 \\
\hline
\end{tabular}

Source: T. M. Smirnowa, Nacjonalnost'- Piterskije. Nacjonalnyje mienszestwa Pieterburga i leningradskoj oblasti w XX wiekie, SPb 2002, p. 66, 82, 83.

It needs to be noted that a multinational character of settlement was present also within the St Petersburg-Petrograd-Leningrad provinces and later in the Leningrad Oblast. According to the census conducted in 1897 St Petersburg province was inhabited by 847,000 people. The greatest nonRussian minority were ingermanland Finns - 109,400 (12.9\%), Estonians - 51,800 (6.1\%), and Germans - 13,500 (1.6\%). Other significant groups were autochthonic Izhorians - 13,700 (1.6\%), Karelians - $800(0.09 \%)$ and Vepsians $-300(0.03 \%)^{17}$. According to the census from 1926 Leningrad

17 Data in the period of T. M. Smirnowa, Nacjonalnost'- Piterskije. Nacjonalnyje mienszestwa Pieterburga i leningradskoj oblasti w XX wiekie, St Petersburg 2002, p. 67. 
province was inhabited by 1,2 million people, and Russians constituted nearly $80 \%$. Finns accounted for 119,000 (10.1\%), Estonians 50,500 (4.3\%), Germans 8,300 (0.7\%), Vepsians 12,900 (1.1\%), Latvians 6,500 (0.6\%), and Jews 3,700 $(0.3 \%)^{18}$. The census from 1939 found the Leningrad Oblast to be inhabited by 3.2 million people, and Russians constituted $90 \%$ of this population. Finns were the largest non-Russian group and accounted for $106,700(3.3 \%)$, followed by Estonians - 44,500 (1.4\%), Germans 12,800 (0.4\%), Vepsians 15,600 (0.5\%), Jews 17,700 (0.5\%) and Latvians 11,600 $(0.4 \%)$. Despite the fact that the 1939 census purportedly increased, it can be noticed that it showed a decrease in the number of Finnish and Estonian rural inhabitants. This decrease was caused by dekulakization and mass resettlements in the period of collective farming and deportations in the $1930 \mathrm{~s}^{19}$.

Further changes in the ethnic structure of Leningrad followed the Second World War. Despite the demographic losses resulting from military operations and the tragic Leningrad blockade, the city still maintained its multinational character. According to the first post-war census in 1959, the number of non-Russians was $372,000^{20}$. In the following decades this number increased from 438,000 in 1970 to 541,800 in 1989. In the Leningrad diasporas the number of Tatars systematically increased, from 27,000 in 1959 to 44,000 in 1989, as well as Ukrainians from 68,000 to 151,000 and Belorussians from 47,000 to 93,000 respectively. However, the number of Jews, Poles, Germans, Estonians and Latvians decreased. A steady increase was also noted in Caucasian nationalities: Azerbaijani, Georgians, Armenians and also Bashkirs, Kazachs and representatives of other non-European Soviet republic. The last census in Leningrad was conducted in 1989 and has been used as a demographic basis of statistic data for St Petersburg since 1991.

Despite the significant efforts Stalinism and its increase in regime repressions the multinational character of Leningrad was not erased. The life of ethnic minorities, although secretive, was still smouldering. The rebirth of cultural life among national minorities in St Petersburg started

18 Data in the period of. С. Лаллукка, Штрихи к этнической карте северо-запада России (1926 - 1959), [in:] Т. Вихавайнен, И.Такала (Ed.), В семье единой: национальная политика большевиков и её осуществление на Северо-Западе России в 1920 - 1950-е года, Petrograd 1998, p. 56.

${ }^{19}$ Ibidem

20 After the Second World War censuses in Leningrad were conducted in 1959, 1970, 1979 and 1989. 


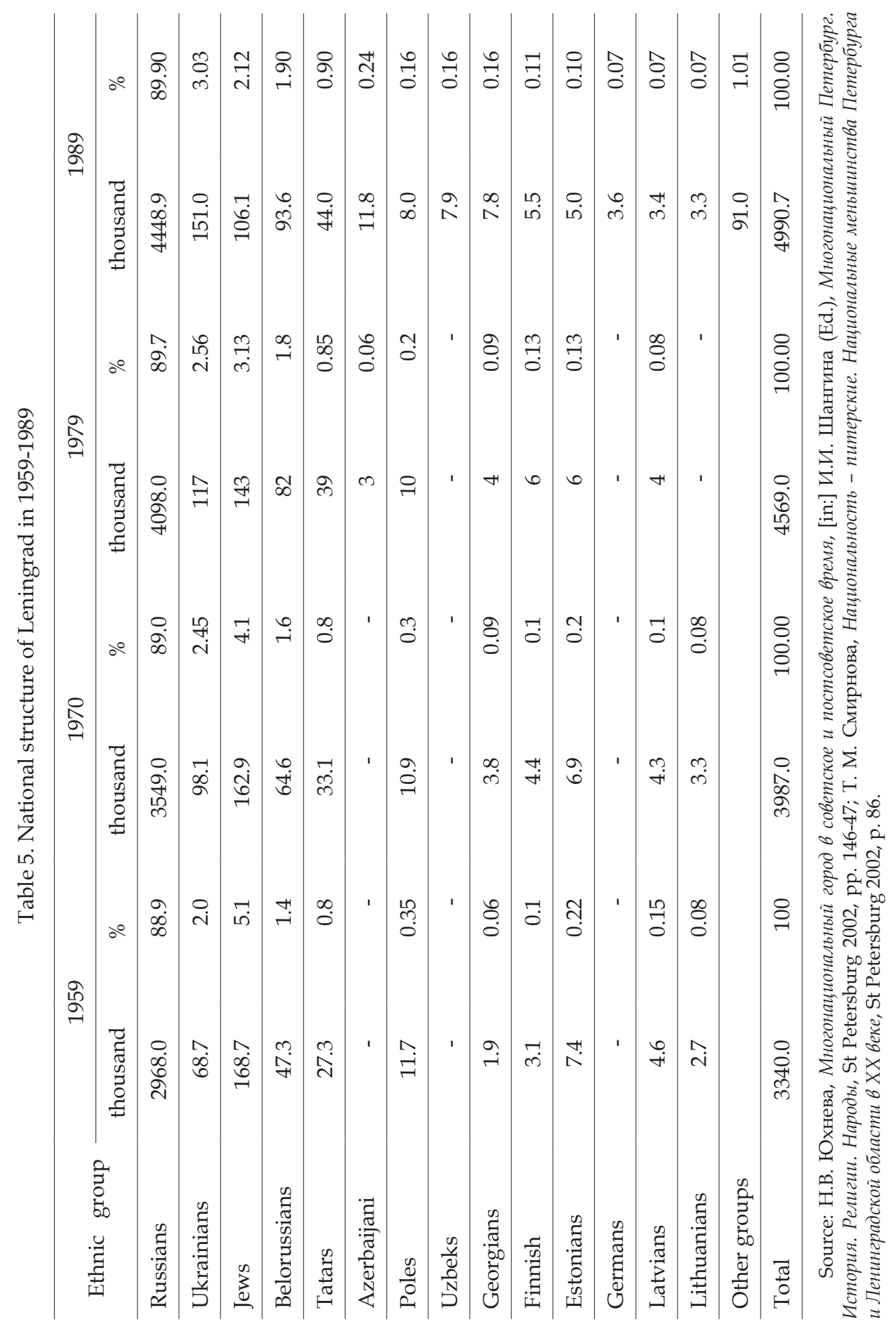


in the 1980s together with perestroika. Thanks to the initiated liberalization by Mikhail Gorbachev and together with the development of legislation in the Russian Federation, including the protection of human rights and ethnic minorities, the renaissance of educational, social, secular and sacral national institutions began and, with variable dynamics, has lasted until today. Since the 1990s in Leningrad-St Petersburg various forms of institutional activities have been revived: national minority organisations (associations, unions, societies, institutions, clubs), national press, schools, and so on. In the first half of the 1990s, there was a social revival of St Petersburg's communities: Germans, Poles, Ukrainians, Belorussians, Latvians, Estonians, Jews, Azerbaijani, Armenians, Tatars, Georgians, Yakuts, Afghans, Bashkirs, Koreans and others. St Petersburg's Polonia is the prime example of the revival of national traditions by Neva.

"After the long period of non-existence since 1937, after a thorough uprooting of social, cultural, educational life, no Polish organisation or institution was expected to ever grow again on St Petersburg soil. And yet! St Petersburg's Polonia regained its new status at the end of 80s. This process was preceded by political changes - perestroika - and the development of social movements in USSR: national fronts in Latvia, Estonia, and the Sajudis in Lithuania. The idea to establish $<<$ little Poland in Saint St Petersburg>> was developed"21. The first Polish organisation, which was founded in 1989, was "Polonia", and it was a social-cultural association 22.

Apart from organisations connected with various minorities, regional organisations of coordinating nature were also established. They were social and scientific institutions that handled the issues of nationalist politics and the current situation of diasporas within the city and Oblast. In 1989 in Leningrad the Centre of Friendship of Peoples of the USSR was established - the first organisation of this kind. In 1992 the Centre was reorganised into the Saint St Petersburg House of National Cultures. The statutory goal of the House was to coordinate the activities of national organisations in the city, educational activities, scientific conferences, concerts, exhibitions, preparation of adaptive expertise and other enterprises aimed at the maintenance of self-awareness, traditions and habits of non-Russian communities of St Petersburg ${ }^{23}$.

\footnotetext{
${ }^{21}$ T. Konopielko (red.), Polacy w Sankt Petersburgu, Lublin 2012, p. 11.

22 Official website of organisation: www.polonia.spb.ru

${ }^{23}$ Official website of organisation www.spbdn.ru
} 
Bartłomiej Garczyk - PhD, he currently works as Assistant Professor at the Institute of Eastern Researches. Scientific interests: history of tsarist Russia, history of the Soviet Union and the Russian Federation, the phenomenon of St. Petersburg, russian culture and civilization. 